ZESZYTY NAUKOWE UNIWERSYTETU SZCZECIŃSKIEGO

NR 867 PROBLEMY ZARZĄDZANIA, FINANSÓW I MARKETINGU NR $40 \quad 2015$

DOI: $10.18276 /$ pzfm.2015.40-03

\author{
AGNIESZKA ŁUKASIEWICZ-KAMIŃSKA ${ }^{1}$ \\ Cardinal Stefan Wyszyński University, Warsaw
}

\title{
SUSTAINABLE CITY MARKETING: A MODERN MANAGEMENT MODEL
}

\begin{abstract}
Summary
The purpose of this paper is a theoretical reconstruction of the principles of the concept of sustainable city marketing as a modern management model, based on a survey of the literature. The paper also presents the concept of sustainable development as the foundation of sustainable marketing. The concept of sustainable development is a solution to current global economic, environmental and social problems. It has become a principle acknowledged worldwide at almost all levels of administration and in corporate practice. Sustainable marketing is a management concept reflecting the implementation of sustainable development principles in marketing. Sustainable marketing should become an inherent part of policy documents and an important management tool.
\end{abstract}

Keywords: sustainable development, sustainable city marketing, management

\section{Introduction}

The transformation of social, economic and political systems, EU membership coupled with the development of knowledge-based economy and global competitiveness make it necessary for cities to be active in the competitive market in order to attract and retain investors, as well as improve the quality of life of their inhabitants. A city becomes a kind of enterprise, an organisation which pursues various goals and combines a variety of frequently conflicting functions, in line with economic calculation and the idea of sustainable development.

The idea of sustainable development is a solution to current global economic, environmental and social problems. Its implementation is reflected by the

\footnotetext{
11agnieszka.lukasiewicz@uksw.edu.pl.
} 
changes in marketing towards its conformity with the principles of sustainable development "which is the most socially responsible form of satisfying the needs."

The purpose of this paper is a theoretical reconstruction of the principles of the concept of sustainable city marketing as a modern management model, based on a survey of the literature. The paper also presents the concept of sustainable development as the foundation of sustainable marketing.

\section{The concept of sustainable development}

The concept of sustainable development is becoming increasingly important both in its theoretical dimension and its impact on EU economic policies and on business practices. The European Parliament, actively promoting this concept, has stated that "more corporate social and environmental responsibility is one of the fundamental elements of the European social model and the European sustainable development strategy." 3 Today, apart from pursuing strictly economic goals, businesses are expected to serve their environment by taking action for the benefit of the people and the natural environment.

The idea of sustainable development was presented in the 1987 report of the Brundtland Commission (UN World Commission on Environment and Development) "Our Common Future." The report defines sustainable development as "a process aimed at meeting the development aspirations of the present generation without compromising the aspirations of future generations." ${ }^{.4}$ In 1992, the idea was made public during the 2nd Earth Summit in Rio de Janeiro. At this conference, Agenda 21 action plan was adopted, meant as a global sustainable development strategy. The document identifies the problems of humankind in the 21 st century and ways of solving them. Although Agenda 21 is not a set of binding laws, many countries, the European Union included, consider it as such. Sustainable development was defined as social and economic development which is in line with the requirements of natural environment protection and makes it possible to meet the needs of the present without compromising the ability of future

\footnotetext{
${ }^{2}$ S. Zaremba-Warnke, Koncepcja zrównoważonego rozwoju jako determinanta przeobrażeń marketingu, in: Marketing przyszłości. Trendy. Strategie. Instrumenty. Wieloaspektowość problemów marketingu w jednostkach samorzadu terytorialnego i instytucjach publicznych, ed. A. Smalec, Zeszyty Naukowe Uniwersytetu Szczecińskiego No. 824, Problemy Zarządzania, Finansów i Marketingu No. 35, Wyd. Naukowe Uniwersytetu Szczecińskiego, Szczecin 2014, p. 219.

${ }^{3}$ E. Rudawska, Marketing zrównoważony - nowe oblicze kapitalizmu? „Ekonomia = Economics" No. 3 (24), Wyd. Uniwersytetu Ekonomicznego we Wrocławiu, Wrocław 2013, p. 78.

${ }^{4}$ Unesco a zrównoważony rozwój, http://www.unesco.pl/edukacja/dekada-edukacji-nt-zrownowazonego-rozwoju/unesco-a-zrownowazony-rozwoj (10.07.2013).
} 
generations to meet their own needs. Initially, sustainable development was understood in terms of respect for the natural environment (ecodevelopment). However, it was soon realized that "it is impossible to protect natural environment without respecting the rights of local communities, principles of democracy and people's participation in shaping civic society, without pursuing the elimination of hunger and poverty or the development of entrepreneurship. Therefore, the concept assumes a balance between economic, social and environmental aspects, which is a precondition for maintaining a high quality of life."

Article 5 of the Constitution of the Republic of Poland defines the legal basis for Poland's sustainable development: "The Republic of Poland shall safeguard the independence and integrity of its territory and ensure that freedoms and rights of persons and citizens, the security of the citizens, safeguard the national heritage and shall ensure the protection of the natural environment pursuant to the principles of sustainable development." 6

According to the Environment Protection Act, sustainable development is socio-economic development that integrates political, economic and social activities, while preserving the natural equilibrium and the sustainability of basic natural processes, with the aim of guaranteeing the ability of individual communities or citizens, of both the present and future generations, to satisfy their basic needs. ${ }^{7}$ Poland also has the Strategy for Sustainable Development - Poland 2025 and the National Environmental Policy.

Agenda 21 refers to the catchphrase "Think globally, act locally". It argues that "Governments at all levels, from global to local, face a big responsibility. Decisions should be made at the lowest possible level, however taking into account the interests of people living elsewhere." ${ }^{8}$

Therefore, the idea of sustainable development should be implemented into the practices of companies, regional and local governments, national authorities and other business entities, whose activities can contribute to socio-economic development.

\section{From marketing to sustainable marketing}

Marketing has been developing dynamically since the 1960s. Since then, the

\footnotetext{
${ }^{5}$ E. Jastrzębska, Wprowadzenie do koncepcji CSR i zrównoważonego rozwoju, in: Jak uczyć o społecznej odpowiedzialności i zrównoważonym rozwoju. Przewodnik dla nauczycieli, ed. J. Reichel, FOB, MG, Warszawa 2011, p. 11.

${ }^{6}$ Constitution of the Republic of Poland 1997, Chapter I, Article 5.

${ }^{7}$ Ustawa z 27 kwietnia 2001 r. Prawo ochrony środowiska, DzU z 2001, No. 62, item 627.

${ }^{8}$ www.republika.pl/edukacja-humanitarna/pdf/przew_agenda_21.pdf (5.03.2015).
} 
approach to marketing has evolved. It is believed that initially marketing was oriented at creating the demand for various goods and services, and thus stimulating excessive consumerism, encouraging excessive consumption and overproduction in order to maximise company profits.

In the 1970s, public attention was drawn to the natural environment and environmental issues. As a result, the idea of sustainable marketing was conceived in the late 1990s. The first to use the term were Sheth and Parvatiyar in 1995 and they are considered to be the authors of the concept.

Sustainable marketing has developed on the basis of a number of related concepts, such as corporate social responsibility, sustainable development, the stakeholder theory, stakeholder marketing, social marketing, green marketing, ecological marketing, cause related marketing or environmental marketing.

Initially, it was thought that marketing and sustainable marketing were concepts based on contradictory assumptions: "Marketing is still frequently perceived as an idea oriented at an increase in production and sale, while the idea underlying sustainable marketing is to curb consumption $[\ldots]$ - sustainable development is the antithesis of marketing." 9 Therefore, it was reasonable to look for ways to combine these concepts. "Current marketing concepts emphasize the fact that businesses need to engage in broadly understood socially and environmentally oriented activities. [...] Marketing therefore, is connected with the three dimensions of sustainable development mentioned above at micro level and encompasses relations and attitudes of market entities in the whole value chain. In this context, marketing can be perceived as an element included in the concept of sustainable development and all the activities supporting it." ${ }^{10}$ Marketing should contribute to the improvement of the quality of life of citizens - a macro approach. ${ }^{11}$

There are many definitions of sustainable marketing; some of them are discussed below. I. Wilk argues that sustainable marketing is "the process of creating, communicating and supplying values to consumers in such a way so as to protect and enrich natural and human capital. Natural capital encompasses all the

\footnotetext{
${ }^{9}$ Ibidem, p. 78 .

${ }^{10} \mathrm{~S}$. Hunt, Sustainable marketing, equity, and economic growth: a resource-advantage, economic freedom approach, "Journal of the Academy of Marketing Science" 2011, Vol. 39, No. 1, p. 7-20.

${ }^{11}$ Ibidem, p. 79.
} 
resources provided by the environment, while human capital ${ }^{12}$ is resources coming from people, including work, talent, creativity. It can be stated that the purpose of sustainable marketing is to help create a society where seeking sustainable development is the norm." ${ }^{\prime 3}[\ldots]$ While defining sustainable marketing, we should emphasize its comprehensive involvement in economic, environmental and social aspects. Therefore, sustainable marketing can be defined as building and maintaining sustainable relations with clients, the social environment and the natural environment."14

S. Zaremba-Warnke defines sustainable marketing as "the process of identifying and satisfying the needs of consumers and society by planning and realizing the concepts of prices, promotion and distribution of ideas, goods and services in a way which is both satisfying to the parties to the exchange and sustainable. [...] Sustainable marketing encompasses integrated environmental, economic and socio-cultural goals, and is consistent with the goals of sustainable economy. [...] Sustainable marketing is a marketing of a better present and a better future, a better quality of life for the present and future generations." 15

Sustainable marketing is "the process of planning, organizing and implementing marketing programmes related to the development of goods, prices, methods of sale and promotion in the way which: (1) satisfies clients and their needs; (2) makes it possible for companies to accomplish their goals; and (3) ensures the compatibility of these processes with the ecosystem". ${ }^{16}$

Sustainable marketing is a concept of management reflecting the implementation of the principles of sustainable development in marketing. After translating them into marketing activities and instruments, new possibilities of creating and offering more environmentally and socially sustainable goods and services are created. This approach comes down to securing social equity as well as environmental and economic equilibrium. The three elements are referred to as the $3 \mathrm{Es}$ in the literature of the subject. ${ }^{17}$

\footnotetext{
12 It must be noted that there is a difference between "human capital" and "human resources": "resources" are something to be used, while "capital" is something to invest in.

${ }^{13}$ D. Martin, J. Schouten, Sustainable marketing, Prentice Hall, Boston 2012, p. 10.

${ }^{14}$ I. Wilk, Aktywność marketingowa przedsiębiorstw w warunkach zrównoważonego rozwoju, in: Marketing przyszłości. Trendy. Strategie. Instrumenty. Orientacja marketingowa jednostek samorzadu terytorialnego i instytucji publicznych, ed. A. Smalec, Zeszyty Naukowe Uniwersytetu Szczecińskiego No. 775, Problemy Zarządzania, finansów i Marketingu No. 30, Wyd. Naukowe Uniwersytetu Szczecińskiego, Szczecin 2013, p. 280-281.

${ }^{15} \mathrm{~S}$. Zaremba-Warnke, Koncepcja zrównoważonego rozwoju ..., p. 223.

${ }^{16}$ Ibidem, p. 81.

${ }^{17}$ Ibidem, p. 7-20.
} 


\section{Sustainable city marketing}

One of the tiers of government in Poland is the municipality or the urban county. A city is a high density built-up settlement unit, densely populated, with limited green areas and scarce agricultural areas. Sustainable city development means activities in the following areas:

a) socio-economic space: e.g. identifying and satisfying local needs of the inhabitants regarding their participation in planning, decision making and access to basic services, creating new jobs, fighting poverty, solving demographic problems and introducing social security, ensuring equal opportunities and integration regardless of gender, age, ethnicity, etc., delivering healthcare, quality of life, and safety \& security;

b) environmental space - activities for the natural environment, protection of nature by e.g. control of greenhouse gas emission, noise levels, air and water pollution the use of natural resources, a waste generation; waste management, sustainable efforts to ensure healthy living conditions by eliminating radiation, harmful substances, etc.;

c) economic space - e.g. an attractive offer for investors, economic stability, city image creation, public-private partnership projects.

It can also be demonstrated that the city is a kind of enterprise. "In a new reality, cities, like enterprises, started to be subject to market laws, they have been forced to compete with each other in order to attract and retain investors, attract tourists and be positively perceived by their inhabitants. Particularly actively do they compete for external financial support, e.g. EU funds, which makes it necessary for city authorities to be more active as regards marketing and more enterprising than before. As a result, promotion has become very important in building the competitive edge." 18 This is why cities undertake numerous marketing actions. One of the concepts of city marketing is sustainable city marketing.

Sustainable city marketing should be characterized by activities consistent with the idea of sustainable development. The use of the idea of sustainable city marketing requires the following:

1. The will to act for sustainable development, with a strong belief that environmental, economic and socio-cultural goals are equally important; ultimately, all the goals of sustainable economy should be taken into account.

\footnotetext{
${ }^{18}$ D. Lustyk, Społeczna odpowiedzialność biznesu w kreowaniu wizerunku miasta, w: Kreowanie wizerunku miast, eds. A. Grzegorczyk, A. Kochaniec, Wyższa Szkoła Promocji, Warszawa 2011, p. 147-148.
} 
2. The development of a strategy for the city that includes activities for sustainable development - "regarding needs related to sustainable development as a benchmark for all activities," 19 and sustainable marketing efforts.

3. Presentation of the idea of sustainable development to the public and making them aware of its problems - education of city stakeholders.

4. The development of surveys to indentify sustainable development related needs.

5. The involvement of all city stakeholders in activities for sustainable development.

6. The improvement of communication with city stakeholders in order to emphasize the sustainable nature of the activities - the city should undertake numerous advertising and promotion campaigns providing solid, reliable and systematic information on socio-ecological activities for city stakeholders.

7. The adjustment of communication to the actual needs of the target group.

8. Full openness and transparency of all the activities.

9. Activities that should be ethical and entail responsibility for their consequences. "The ethics of sustainable development formulates the following basic principles: the principle of equitableness within the generation (intragenerational fairness and solidarity), the principle of equitableness between generations, the precautionary principle, the nature's autonomous rights to protection, peace and harmony with the common world, seeking an appropriate measure, the recognition of sustainable democracy. [...] The ethics of sustainable development must always include the responsibility principle (i.e. willingness to work for the benefit of others). ${ }^{20}$

10. Inclusion of effects of sustainable economy goals in the marketing performance indicators.

11. Shift of focus from competition to cooperation." 21

12. The use of appropriate tools in practice - according to the survey carried out by The Economist and Marketo ${ }^{22}$ among nearly 500 marketing directors all over the world, marketing activities in the coming years will be oriented at social media, marketing analytics, mobile marketing, email marketing, personalization of offers with the use of mobile devices in real time, etc.

\footnotetext{
${ }^{19}$ S. Zaremba-Warnke, Koncepcja zrównoważonego rozwoju ..., p. 224.

${ }^{20}$ H. Rogall, Ekonomia zrównoważonego rozwoju. Teoria i praktyka, Wyd. Zysk i S-ka, Poznań 2010, p. 199.

${ }^{21}$ S. Zaremba-Warnke, Koncepcja zrównoważonego rozwoju ..., p. 224.

22 R. Kozielski, Jeszcze szybsze zmiany czyli przyszłość marketingu, http://biznes.pl/magazyny/marketing/jeszcze-szybsze-zmiany-czyli-przyszlosc-marketingu/dhkket (2.04.2015).
} 
13. Marketing activities which will provide values for individual groups of stakeholders - the idea of sustainable development includes such basic values as equitableness (every human being wants to live in a fair society), responsibility for themselves and their actions, and also responsibility for others a commitment to be responsible for nature and all the creatures living now and in the future. [...] The source of this sense of responsibility is empathy and willingness for action. ${ }^{, 23}$ Other values include seeking harmony and freedom for all.

\section{Conclusions}

The idea of sustainable development is increasingly becoming the basis of economic policy. "Today, three pillars of sustainable development are recognized: society, environment and economy, which are inseparably connected with each other." 24

The dynamic development of marketing, which started in the 1960s, and its transformation oriented at measures to improve people's quality of life have led to the emergence of sustainable marketing. Sustainable marketing is a concept of management which illustrates the implementation of sustainable development principles in marketing. Sustainable marketing should be permanently inscribed in policy documents. Today, marketing must be understood in broader terms "not only as activities resulting in customer satisfaction and in meeting their needs while accomplishing economic goals, but also as activities the effects of which would have a positive impact on future generations. [...] Enterprises' economic goals, particularly in the economy based on knowledge and global competition, and social and environmental goals are interrelated, they supplement and support each other. As a result, the implementation of sustainable marketing concept translates into designing such activities which are at the same time economically viable, environmentally friendly and socially responsible in the long run." 25

As E. Rudawska argues, "sustainable marketing will not suggest ultimate solutions to current socio-environmental problems, and only reconciliation of activities on micro and macro levels (in the form of governmental regulations on

\footnotetext{
${ }^{23}$ H. Rogall, Ekonomia ..., p. 197.

${ }^{24}$ A. Łukasiewicz-Kamińska, Wptyw działalności sektora bankowego na zrównoważony rozwój, in: Nierówności spoleczne a wzrost gospodarczy, No. 37. Wyd. Uniwersytetu Rzeszowskiego, Rzeszów 2014, p. 355-365.

${ }^{25}$ Ibidem, p. 86.
} 
environmental policies and cooperation of international organizations) may bring a lasting effect, ensuring the development and existence of future generations." ${ }^{26}$

\section{Bibliography}

Constitution of the Republic of Poland 1997, Chapter I, Article 5.

Hunt S., Sustainable marketing, equity, and economic growth: a resource-advantage, economic freedom approach, "Journal of the Academy of Marketing Science" 2011, Vol. 39, No. 1.

Jastrzębska E., Wprowadzenie do koncepcji CSR i zrównoważonego rozwoju, in: Jak uczyć o społecznej odpowiedzialności i zrównoważonym rozwoju. Przewodnik dla nauczycieli, ed. J. Reichel, FOB, MG, Warszawa 2011.

Kozielski R., Jeszcze szybsze zmiany czyli przyszlość marketingu, http://biznes.pl/magazyny/marketing/jeszcze-szybsze-zmiany-czyli-przyszlosc-marketingu/dhkket.

Lustyk D., Społeczna odpowiedzialność biznesu w kreowaniu wizerunku miasta, w: Kreowanie wizerunku miast, eds. A. Grzegorczyk, A. Kochaniec, Wyższa Szkoła Promocji, Warszawa 2011.

Łukasiewicz-Kamińska A., Wpływ działalności sektora bankowego na zrównoważony rozwój, in: Nierówności spoteczne a wzrost gospodarczy, No. 37. Wyd. Uniwersytetu Rzeszowskiego, Rzeszów 2014.

Martin D., Schouten J., Sustainable marketing, Prentice Hall, Boston 2012.

Rogall H., Ekonomia zrównoważonego rozwoju. Teoria i praktyka, Wyd. Zysk i S-ka, Poznań 2010.

Rudawska E., Marketing zrównoważony - nowe oblicze kapitalizmu? „Ekonomia = Economics" No. 3 (24), Wyd. Uniwersytetu Ekonomicznego we Wrocławiu, Wrocław 2013.

Unesco a zrównoważony rozwój, http://www.unesco.pl/edukacja/dekada-edukacji-ntzrownowazonego-rozwoju/unesco-a-zrownowazony-rozwoj.

Ustawa z 27 kwietnia 2001 r. Prawo ochrony środowiska, DzU z 2001, No. 62, item 627.

Wilk I., Aktywność marketingowa przedsiębiorstw w warunkach zrównoważonego rozwoju, in: Marketing przysztości. Trendy. Strategie. Instrumenty. Orientacja marketingowa jednostek samorzadu terytorialnego i instytucji publicznych, ed. A. Smalec, Zeszyty Naukowe Uniwersytetu Szczecińskiego No. 775, Problemy Zarządzania, finansów i Marketingu No. 30, Wyd. Naukowe Uniwersytetu Szczecińskiego, Szczecin 2013.

www.republika.pl/edukacja-humanitarna/pdf/przew_agenda 21.pdf.

Zaremba-Warnke S., Koncepcja zrównoważonego rozwoju jāko determinanta przeobrażeń marketingu, in: Marketing przyszłości. Trendy. Strategie. Instrumenty. Wieloaspektowość problemów marketingu w jednostkach samorzadu terytorialnego i instytucjach publicznych, ed. A. Smalec, Zeszyty Naukowe Uniwersytetu Szczecińskiego No. 824, Problemy Zarządzania, Finansów i Marketingu No. 35, Wyd. Naukowe Uniwersytetu Szczecińskiego, Szczecin 2014.

${ }^{26}$ Ibidem, p. 85. 


\title{
ZRÓWNOWAŻONY MARKETING MIASTA: NOWOCZESNY MODEL ZARZĄDZANIA
}

\begin{abstract}
Streszczenie
Celem artykułu jest teoretyczna rekonstrukcja założeń koncepcji marketingu zrównoważonego miasta, jako nowoczesnego modelu zarządzania, przeprowadzona na podstawie badania literaturowego. Została również przedstawiona koncepcja zrównoważonego rozwoju stanowiąca podstawę dla marketingu zrównoważonego. Koncepcja zrównoważonego rozwoju jest odpowiedzią na współczesne globalne problemy ekonomiczne, ekologiczne i społeczne. Stała się uznawaną w świecie zasadą na prawie wszystkich szczeblach administracji oraz w praktyce działania firm. Marketing zrównoważony jest koncepcją zarządzania będącą wyrazem implementacji zasad zrównoważonego rozwoju w marketingu. Zrównoważony marketing powinien być trwale wpisany do strategii, stanowić ważne narzędzie w zarządzaniu.
\end{abstract}

Słowa kluczowe: zrównoważony rozwój, marketing zrównoważony miasta, zarządzanie

Ttumaczenie: Agnieszka Łukasiewicz-Kamińska 